Albrecht Berger (Munich)

(iD) https://orcid.org/0000-0002-6666-4083

\title{
Constantine's City: the EArly Days of a Christian Capital
}

\begin{abstract}
Constantine the Great, the first Christian emperor and founder of the new capital Constantinople ${ }^{1}$, was, of course, a central figure in Byzantine state ideology of later centuries. In reality, however, the historical Constantine turned to Christianity only very gradually during his life, and although the conversion of the Roman empire to Christianity and the suppression of paganism certainly began in his age, it was actually a long process which extended over the fourth and fifth into the sixth century $\mathrm{AD}^{2}$.

It is true that the only contemporary biography of the emperor, the Life of Constantine by his friend and counsellor Eusebius of Caesarea ${ }^{3}$, gives us the impression that the violent suppression of paganism was already thoroughly planned and in large parts undertaken in Constantine's own lifetime - an impression which disagrees so much to our modern knowledge that it has led scholars like Henri Grégoire to the assumption that this Life of Constantine was in reality written long after Constantine and Eusebius ${ }^{4}$. But this is, as we know today, not the case, and
\end{abstract}

\footnotetext{
${ }^{1}$ On the foundation of Constantinople and the early stages of its development, see G. DaGron, Naissance d'une capitale. Constantinople et ses institutions de 330 à 451, Paris 1974, p. 13-47; C. Mango, Le développement urbain des Constantinople (IVe-VII siècles), ${ }^{2}$ Paris 1990 [= TM.M], p. 23-36; also D. Lathoud, La consécration et la dédicace de Constantinople, EO 23, 1924, p. 289-314. For the monuments of Constantinople mentioned later in the text, see still R. JANIN, Constantinople byzantine. Développement urbain et répertoire topographique, ${ }^{2}$ Paris 1964.

${ }^{2}$ See, for example A. Cameron, The Last Pagans of Rome, Oxford 2011; R. MacMullen, Christianizing the Roman Empire (A.D. 100-400), New Haven 1984.

${ }^{3}$ Eusebius Werke, vol. I.1, Über das Leben des Kaisers Konstantin, ed. F. Winkelmann, ${ }^{2}$ Berlin 1974 [= GCS, 7.1] (cetera: Eusebius); Eusebius, Life of Constantine, trans. Av. Cameron, S. Hall, New York 1999. See also, in general: T.D. BARnes, Constantine and Eusebius, Cambridge Mass. 1981.

${ }^{4}$ H. Grégoire, La 'conversion' de Constantin, RUB 36, 1930-1931, p. 231-272; IDEM, Eusèbe n'est pas l'auteur de la 'Vita Constantini' dans sa forme actuelle et Constantin ne s'est pas 'converti en 312, B 13, 1938, p. 561-583.
} 
at a closer examination Eusebius' statements do not contain obvious lies, just a lot of selective perception and exaggeration ${ }^{5}$.

Constantine's religious policies were, as is well known, not as Christian as Eusebius and almost all Byzantine authors after him would us make believe. On the one hand, Constantine did definitely not adhere to the traditional Roman religion without criticism, he clearly supported Christianity and presided in person, for example, at the first Ecumenical Council in Nikaia - but on the other hand, he founded his own new city Constantinople and installed there an imperial cult for himself as the Invincible Sun god. Although Constantine received baptism shortly before the end of his life, he was still portrayed as the Sun God ascending to heaven on the consecration coin minted after his death; and his annual procession on the $11^{\text {th }}$ May, which remembered the inauguration of Constantinople in 330, was continued after his death with a statue showing him as the Invincible Sun God, holding the reins of a quadriga in one hand, and a small statue of Tyche, the city goddess of Constantinople, in the other. The four horses of this quadriga, which are now kept at San Marco in Venice, is the last material remain of this ceremony - they were, however, not newly made in Constantin's time, but are reused pieces from the Hellenistic age ${ }^{6}$.

In fact, it took several centuries for the emperor to become an exemplary Orthodox Christian emperor, indeed a saint.

Constantine did not suppress pagan cult practices altogether, but certain excessive forms of them which may have offended also more intellectual followers of the old religion, such as bloody sacrifices of animals or sacred prostitution often associated with the cult of Aphrodite ${ }^{7}$. There is only one place where a pagan temple was completely destroyed in his lifetime, namely Jerusalem, where the Roman temple of Aphrodite was replaced by the church of the Holy Sepulchre ${ }^{8}$. But in many other cases, where temples were closed and their cult suppressed, no Christian church was established in their place instead.

Eusebius claims, also in his Life of Constantine, that the emperor prohibited the imperial cult by law ${ }^{9}$ - something which is difficult to understand, especially if we look at what was going on in Constantinople in the first years and decades after its foundation.

\footnotetext{
${ }^{5}$ M. WAllraff, Die antipaganen Maßnahmen Konstantins in der Darstellung des Euseb von Kaisareia, [in:] Spätantiker Staat und religiöser Konflikt. Imperiale und lokale Verwaltung und die Gewalt gegen Heiligtümer, ed. J. HaHN, Berlin 2011 [= Mil.S, 34], p. 7-18.

${ }^{6}$ On which see M. JAcoff, The Horses of San Marco and the Quadriga of the Lord, Princeton N.J. 1993.

${ }^{7}$ T.D. Barnes, Constantine's Prohibition of Pagan Sacrifice, AJP 105, 1984, p. 69-72.

${ }^{8}$ See M. WAllrafF, Die antipaganen Maßnahmen..., p. 12; for the church see, for example, C. CoüAsNON, The Church of the Holy Sepulchre in Jerusalem, London 1974.

${ }^{9}$ Eusebius, IV, 16.
} 
As late as in 333, a temple of the imperial family was newly built in Hispellum in Umbria, but its Latin inscription gives the order that - I quote - the house dedicated in our name should not be polluted by any infectious deceit of superstition - which means, probably, by bloody sacrifices in front of the emperor's statue ${ }^{10}$.

So what was Constantine's own religious concept? The best definition I know comes from Martin Wallraff, my colleague in Munich, who said ${ }^{11}$ :

There is some evidence that Constantine had a kind of paganism in mind as the state religion which was purified by Christianity, a Hegelian synthesis, as it were, of the respective best parts of the empire's different religious traditions - a synthesis which probably nobody really understood among his contemporaries, and nobody really wanted. This programme can be particularly well understood from the profile of his newly founded capital on the Bosporus.

This is very true, for the imperial cult staged by Constantine in Constantinople was something rather peculiar, and although nobody may have wanted it, it was still alive and practised in his city for about twenty years after his death. Then, however, his son Constantius began to push the rather oppressive memory of his father into the background by actually making Constantinople a new, Christian capital, granting it the same rights as Rome, establishing a senate, appointing a city prefect, and building churches instead of imperial temples ${ }^{12}$.

When Constantine died in 337, the city was not much more than a monstruous construction site in which only few new building had been completed, among them the first nucleus of the Great Palace with the Hippodrome, and the centres of his imperial cult, namely the Forum, the Capitol, and his mausoleum. It took forty more years until the new part of the city was filled with houses, until a water supply line was in operation, and until the colonnaded streets had reached the city walls in the west. And what is most important: no major church was built in the city during Constantine's reign. The so-called "old church" in the city centre, today known as Saint Eirene, existed already before the city was refounded ${ }^{13}$. The first Great Church, later called Hagia Sophia, which had probably been built as a temple or assembly hall for the imperial cult of Constantine, was converted into a church only in $361^{14}$, and the church of the Apostles in $370^{15}$.

The urban development speeded up only when Theodosius I came to power in 379. Theodosius soon proclaimed Christianity in its orthodox form as the state

\footnotetext{
${ }^{10}$ See R. VAN DAm, The Roman Revolution of Constantine, Cambridge 2007, p. 23-34.

${ }^{11}$ See M. Wallraff, Die antipaganen Maßnahmen..., p. 14.

${ }^{12}$ G. Dagron, Naissance... p. 86-89, 124-135, 226-230, 388-409.

${ }^{13}$ Ibidem, p. 392-393.

${ }^{14}$ P. Speck, Das Konzept Konstantins des Großen für Konstantinopel: Die Umgestaltung der Audienzhalle zur Hagia Sophia und das Schicksal des Kapitols, [in:] IDEM, Varia 7, Bonn 2000, p. 157-165; G. DAgron, Naissance ..., p. 397-399.

${ }^{15}$ G. Dagron, Naissance..., p. 401-409.
} 
religion, and effectively began to suppress paganism, closing, for example, the last pagan temples in Constantinople in $386^{16}$. But all this happened without invoking Constantine the Great, and a few decades later we can even observe that buildings from Constantine's age, which bore the name of a member of his family, were restored and renamed after members of the Theodosian dynasty ${ }^{17}$.

The foundation of Constantinople and its history in the first years are described by contemporary sources only very briefly. The political propaganda of the fourth and fifth century did its best to suppress the memory of Constantine's not-so-Christian religious policies - but one part of it visibly remained in the city, and there was no easy way to make it disappear. This is the decoration with ancient statues, that is, with works of Greek and Roman art which mostly showed pagan gods $^{18}$. But did these statues really convey an ideological statement supporting the old, pagan imperial cult and state religion?

Here we have, first of all, a major problem of historical evidence: except for a short remark in the Life of Constantine by Eusebius of Caesarea, which will be discussed below, no contemporary source speaks about the statues of Constantinople. The Chronicle of Jerome, for example, in which we find the famous saying: Constantinopolis dedicatur omnium paene urbium nuditate (Constantinople was dedicated by denudating almost all cities $)^{19}$, was written about forty years after Constantine's death. All these statues are today lost, and the few pictures from the Byzantine age which show them are mostly conventionalised or simplified ${ }^{20}$. To talk about the statues of Constantinople, therefore, mainly means to discuss the sources where they are mentioned.

Most information about the statues of Constantinople is contained in literary works of a much later time and of more popular character. The most important of them is the Parastaseis syntomoi chronikai, a collection of short notes and stories about the statues of Constantinople which was compiled in the eighth or ninth century ${ }^{21}$. It does not aim at a detailed and objective description of the statues, but tries to connect them to the local history of Byzantium by identifying them either with historical persons, or by explaining them either as pagan magical devices or predictions of the future.

\footnotetext{
${ }^{16}$ Ibidem, p. 374-376.

${ }^{17}$ A. Berger, Regionen und Straßen im frühen Konstantinopel, IM 47, 1997, p. 351, 363.

${ }^{18}$ See the comprehensive survey by S. BAssetr, The Urban Image of Late Antique Constantinople, Cambridge 2004; I am currently preparing a study entitled The statues of Constantinople.

${ }^{19}$ Eusebius Werke, vol. VII, Hieronymi Chronicon, ad annum 330, ed. R. Helm, Berlin 1956 [= GCS, 47], p. 232.

${ }^{20}$ C. MANGO, Antique Statuary and the Byzantine Beholder, DOP 17, 1963, p. 53-75.

${ }^{21}$ Edition and translation: Constantinople in the Early Eighth Century. The Parastaseis Syntomoi Chronikai, ed. Av. Cameron, J. Herrin, Leiden 1984 [= CSCT, 10] (cetera: Parastaseis); for the date, see also P. Odorico, Du recueil à l'invention du texte: le cas des Parastaseis syntomoi chronikai, BZ 107, 2014, p. 755-784.
} 
Another such text, the so-called Patria, was compiled in the late tenth century mostly of older material from the sixth to ninth centuries, including the Parastaseis ${ }^{22}$.

A third important source for the monuments and statues of Constantinople are the poems of Constantine of Rhodes, a well-known author in the first half of the tenth century. Only a part of his poems on Constantinople has survived in their original shape, but more of them are quoted in the chronicle of Georgius Cedrenus, apparently from a more complete version of the text $\mathrm{t}^{23}$.

Nicetas Choniates, the well-known historian, finally described the destruction of most ancient statues by the crusaders of the Fourth Crusade in $1204^{24}$.

All these sources, however, have one thing in common: They contain much information, for example about the foundation of Constantinople, which is unknown from older texts, and of which it is very difficult to imagine, given the popular character of these texts, how it could have possibly reached them after centuries of silence. I shall illustrate this problem with only one striking example:

One of the most impressive ancient statues in Constantinople was a monumental, over life-sized Hercules which stood in the Hippodrome until it was destroyed by the Crusaders in 1204 . Hercules was shown in a crooked position, sitting on his lion's skin spread over a basket, with one hand on his face. This statue is a well-known object of ancient art: it was cast by the famous sculptor Lysippus for the city of Tarento and came to Rome as a trophy in $209 \mathrm{BC}^{25}$. But only the Parastaseis contain the information that it was brought to Constantinople in the time of Julian the consularis, together with twelve other statues - probably those representing the zodiac which are also mentioned later in the Hippodrome ${ }^{26}$. The only Julian who bore this title is the city prefect of Rome from 326 to 329 , which means that the statue must have arrived at Constantinople very early, even before the city was inaugurated in 330, and therefore was part of its initial decoration. The authors of the Parastaseis in eighth-century Constantinople can hardly have invented this detail, but where in heaven could they have found it? Since it was an enormous task to transport such a huge object from Rome to the new city, it must have been brought there not as a mere piece of decoration, but as a pagan symbol of the emperor's power.

\footnotetext{
${ }^{22}$ Patria Constantinopoleos, [in:] Scriptores originum Constantinopolitanarum, vol. II, rec. T. Preger, Lipsiae 1907 [= BSGR] (cetera: Patria). A translation: Accounts of Medieval Constantinople. The Patria, trans. A. BERger, Cambridge Mass. 2013 [= DOML, 24].

${ }^{23}$ Constantine of Rhodes, On Constantinople and the Church of the Holy Apostles, ed. L. James, I. Vassis, trans. V. Dimitropoulou, L. James, R. Jordan, Farnham 2012; Georgii Cedreni Historiarum compendium, ed. L. TARTAGLia, Roma 2016 [= BC, 30] (cetera: Cedrenus).

${ }^{24}$ Nicetae Choniatae historia, rec. J. van Dieten, Berolini 1975 [= CFHB.SBe, 11] (cetera: Nicetas), p. 648.10-655.3; translation: H. Magoulias, O City of Byzantium. Annals of Niketas Choniates, Detroit 1984 .

${ }^{25}$ For a detailed description of this object, see: NiCETAS, p. 519.44-51, 649.84-650.9.

${ }^{26}$ Parastaseis, c. 37.
} 
Let us now return to the question posed before, namely whether these statues really conveyed an ideological statement supporting the old, pagan imperial cult and state religion. Our earliest source about statues in the city is the Life of Constantine by Eusebius of Caesarea who says of the emperor Constantine ${ }^{27}$ :

He displayed the sacred bronze figures, of which the error of the ancients had for a long time been proud, to all the public in all the squares of the Emperor's city, so that in one place the Pythian was displayed as a contemptible spectacle to the viewers, in another the Sminthian, in the Hippodrome itself the tripods from Delphi, and the Muses of Helicon at the palace. The city named after the Emperor was filled throughout with objects of skilled artwork in bronze dedicated in various provinces. To these same, under the name of gods, those sick with error had for long ages vainly offered innumerable hecatombs and whole burnt offerings, but now they had at last learnt sense, as the Emperor used these very toys for the laughter and amusement of the spectators.

Although Constantine the Great is depicted here as a purely Christian emperor whose aim was to destroy all remnants of paganism, we rather get the impression that Eusebius felt obliged to justify somehow the presence of all these pagan statues in the city against his better knowledge. Constantine did not, of course, bring these statues to Constantinople "for the laughter and amusement of the spectators", but with the intention to give them a new, spiritually elevated function in the context of his pagan or semi-pagan state religion. Many ancient statues which were brought to Constantinople in his age were obviously intended for such a religious context, beginning with the main monument of the new city, the emperor's own statue on the column of his new Forum.

The Forum was of circular shape, and built immediately outside the main gate of old Byzantium. It was inaugurated together with the city on the $11^{\text {th }}$ May 330 . The column with its height of almost $40 \mathrm{~m}$ and the gilded, brightly shining statue on top was certainly the most impressive monument of the new city in its first decades ${ }^{28}$.

In the so-called Tabula Peutingeriana, a Roman road map from the fourth century which survives in a Late Medieval copy, a picture of this statue symbolises Constantinople, together with the enthroned city goddess ${ }^{29}$. This representation is small and not very detailed, but the only one which was drawn while the statue still existed.

The first descriptions of the statue are found only in the mid-sixth century, more than two hundred years after Constantine. Hesychius of Miletus speaks of the notable porphyry column, on which Constantine is set, whom we see shining like the sun upon the citizens ${ }^{30}$, while Ioannes Malalas states that he put a statue of himself

\footnotetext{
${ }^{27}$ Eusebius, III, 54, 2-3.

${ }^{28}$ J. Bardill, Constantine, Divine Emperor of the Christian Golden Age, Cambridge 2012, p. 26-34.

${ }^{29}$ M. Rathmann, Tabula Peutingeriana. Die einzige Weltkarte aus der Antike, ${ }^{3}$ Darmstadt 2018.

${ }^{30}$ Hesychii Illustrii origines Constantinopolitanae, c. 41, [in:] Scriptores originum Constantinopolitanarum, vol. I, rec. T. Preger, Lipsiae 1901 [= BSGR] (cetera: Hesychius).
} 
on top of this same column, which had seven rays on its head. He brought this work of bronze which had stood in Ilion, a town of Phrygia ${ }^{31}$.

The claim that the statue was a reused piece of ancient Greek art is often repeated later, and can only be explained if the statue did not show the emperor in the usual military costume ${ }^{32}$. The most plausible assumption is that the statue was, in fact, naked as shown in the Tabula Peutingeriana, and that it wore a crown with seven solar rays. The depiction of a Roman emperor in this shape is not without precedent, the most prominent example being the Colossus of Nero in Rome. In the case of Constantine, the iconography can be explained by his association to the cult of Sol Invictus, the Invincible Sun god. In this phase, which lasted from 310 to 325 , Sol was propagated, among others, as his supporter in the victory over Maxentius in 312, and figures prominently on his Arch in Rome which was built to commemorate this event.

Since it is rather unlikely that a statue of this size and shape was newly made for this purpose, we should assume that actually a statue of a Hellenistic king or a god was reused here. But there is no reason to believe Malalas that it came from Ilion, the Roman successor settlement of Troy, for this claim alludes to the legend that Constantine transferred the legitimate world rule, that of the Trojans, from Rome back to the East - a legend which became popular only in the sixth century when Italy was reconquered from the Goths by the eastern Empire, and an explanation was necessary why emperor Justinian did not return to Rome, but stayed in Constantinople. The statue may instead have been taken from the temple of Helios which is attested in Byzantium before Constantine's time ${ }^{33}$.

The central monument of Constantinople was, therefore, clearly and visibly pagan in character. When the city gradually became Christian after Constantine's death, his naked statue in the shape of the Sun god still stood its column, and if the church historian Philostorgius is right, it still received veneration as a pagan god in the fifth century. Since Philostorgius was regarded as a heretic in later times, most of his work is lost, and is only known from the summary by patriarch Photius from the ninth century who says ${ }^{34}$ :

This impious enemy of God also accuses the Christians of offering sacrifices to an image of Constantine placed upon a column of porphyry, and of honouring it with lighted lamps and incense, and of offering vows to it as to God, and making supplications to it to ward off calamities.

\footnotetext{
${ }^{31}$ Ioannis Malalae Chronographia, 13.7, rec. I. Thurn, Berolini 2000 [= CFHB, 35]; translation: The Chronicle of John Malalas, trans. E. Jeffreys, M. Jefrreys, R. Scott et al., Melbourne 1986 [= BAus, 4].

${ }^{32}$ For the following passage, see J. BARdiLL, Constantine..., p. 33-34.

${ }^{33}$ Ibidem, p. 34, n. 19.

${ }^{34}$ Philostorgius, Kirchengeschichte, II, 17, ed. F. Winkelmann, J. Bidez, ${ }^{3}$ Berlin 1981 [= GCS, 21$]$.
} 
But the longer the statue stood there, the more it became incomprehensible to its Christian beholders. The Forum was experienced as a pagan place, also on account of other ancient statues which stood there, a fact which eventually began to cause troubles for the regular ecclesiastical processions which passed through $\mathrm{it}^{35}$. When the statue finally fell down during a thunderstorm in April 1106, it had become, in the general perception, a purely pagan object whose relationship to the great Christian emperor Constantine was difficult to understand. The historian Anna Comnena reports that, when the statue had fallen, some people took this as a bad omen for her father, the emperor Alexius I Comnenus. But when he was informed about these rumours, he said: I know one lord of life and death, and there is no reason why I should believe that the fall of pagan statues brings death ${ }^{36}$.

Two other monuments from the first phase of the new city, the Capitol and Constantine's mausoleum, were also associated with his imperial cult, but in very different ways.

Let us first discuss the Capitol, which lay about 1.5 kilometers west of the Forum, at the point where a new street to the north-west branched off from the main avenue to the Golden Gate ${ }^{37}$. The Capitol is first mentioned in 407 when its "sign of the cross" was toppled by a thunderstorm ${ }^{38}$. In 427 , it was converted into a law school, and appears under its name only rarely thereafter. Instead, beginning with the Parastaseis, the sources call it "the place of brotherly love", obviously referring to the two pairs of porphyry statues of emperors embracing each other in its eastern portico, which were carried off to Venice after 1204 and now stand at the church of San Marco. The fragment of one foot, which was missing and found in İstanbul, confirms their origin there. This is what the Parastaseis says about them ${ }^{39}$ :

\begin{abstract}
The so-called Philadelphion presents the sons of Constantine the Great. One of them arrived in Constantinople from Gaul after his father's death. They greeted each other with a great meeting and rejoicing, and at once they erected statues of themselves in the city preserving this scene.
\end{abstract}

In reality, Constantine the Great had only three surviving sons, not four, and they fought against each other until only Constantius II was left as the only Roman emperor. The embracing statues do clearly not depict them, but the first four

\footnotetext{
${ }^{35}$ The Forum was finally "christianised" by constructing a chapel near the foot of the column, see C. Mango, Constantine's Porphyry Column and the Chapel of St Constantine, $\mathrm{XXE} 4.10,1981$, p. $103-110$.

${ }^{36}$ Annae Comnenae Alexias, XII, 4, 5, rec. D.R. Reinsch, A. Kambylis, Berolini 2001 [= CFHB, 40].

${ }^{37}$ P. Speck, Das Konzept..., p. 161-163; see now also J. Moralee, Rome's Holy Mountain. The Capitoline Hill in Late Antiquity, Oxford 2018 [= OSLA], p. 104-108.

${ }^{38}$ Chronicon paschale, ed. L. Dindorf, Bonnae 1832 [= CSHB], p. 570.6.

${ }^{39}$ Parastaseis, c. 70.
} 
tetrarchs Diocletian, Maximianus, Galerius, and Constans. They must have originally formed a part of a monument in a tetrarchic residence, probably Nicomedia or Thessalonica, which consisted of two columns of about $8 \mathrm{~m}$ high, on whose shafts the figures were attached in pairs, standing on tables, and with free-standing statues on top of them ${ }^{40}$.

In Rome and other cities, the Capitol was the place where the mythological foundation of Rome was remembered, and where the Capitoline Triad of Jupiter, Juno and Minerva was venerated ${ }^{41}$. Was this also the case in the Capitol of Constantinople, or was Constantine venerated there as a new Jupiter, just as he was venerated as the Sun God in the Forum? And in either case, why should Constantine have decorated his new Capitol with the statues of the Tetrarchs?

To the last question, a plausible, but somewhat surprising answer was given some years ago independently by Philipp Niewöhner and Arne Effenberger ${ }^{42}$ :

When the columns were cut into pieces in order to separate the tetrarchs from them, one was sawn horizontally into drums, while the other was dissected with slightly oblique longitudinal cuts. A result of this is that the group of two emperors on it was also cut in two, and one of them was badly damaged. The explanation for this strange procedure is probably that also an obelisk was cut from out of this columns, for later sources mention an four-sided pillar at the Capitol or Philadelphion which had a cross on it, probably the one which fell in $407^{43}$.

The columns, therefore, were not sawn up in 1204 when the Venetians took the tetrarchs away, but already in the fourth century, when Theodosius I brought them from Thessalonica to Constantinople in 380. The reason for this assumption is, first, that no monumental crosses on columns are attested by other sources before the age of Theodosius I, and second, that the figures were obviously reworked by adding diadems and imperial brooches, and beards to one emperor of every group. This means that they were interpreted as other persons, and in the given case, the three emperors Theodosius, Gratianus and Valentinianus II suggest themselves strongly ${ }^{44}$.

If this is the case, the fourth, more badly damaged emperor must have been set up separately and was only reassembled with the others in Venice centuries later. The identification with the three sons of Constantine, which appears first in the Parastaseis, also suggests a group of three only statues. In the end, only one thing remains inexplicable, namely that the noses and ears of all four figures are

\footnotetext{
${ }^{40}$ P. Verzone, I gruppi di porfido in S. Marco a Venezia ed il Philadelphion di Costantinopoli, Pald 1, 1958, p. 8-14.

${ }^{41}$ J. Moralee, Rome's Holy Mountain..., p. 59-62.

${ }^{42}$ P. Niewöhner, U. Peschlow, Neues zu den Tetrarchenfiguren in Venedig und zu ihrer Aufstellung in Konstantinopel, IM 62, 2012, p. 341-367; A. EFFEnBERGER, Zur Wiederverwendung der venezianischen Tetrarchengruppen in Konstantinopel, Mil 10, 2013, p. 215-274.

${ }^{43}$ P. Niewöhner, U. Peschlow, Neues zu den Tetrarchenfiguren..., p. 359-360.

${ }^{44}$ Ibidem, p. 361.
} 
intentionally mutilated - which means that they were not always interpreted as the representations of Christian emperors, even in Constantinople ${ }^{45}$.

In short: neither the four tetrarchs nor the obelisk with the cross stood at the Capitol in Constantine's age, and we do not need any explication why he should have put these objects there. As to the building itself, we know almost nothing about its shape, except that it had a courtyard and a number of niches where, in later times, law instruction was given ${ }^{46}$.

The Parastaseis, in fact, does not mention the tetrarchs or sons of Constantine in any other entry, but identifies the Philadelphion as the place of his vision of the cross and speaks of four statues sitting on thrones - of Constantine himself, his mother Helena, and his two sons ${ }^{47}$. Could this have been, without the cross of course, the original decoration of the Capitol? And again, where could the authors of this text have known this from? Sitting emperors on thrones at this place did exist and were the last objects of art which had remained at the former Capitol or Philadelphion in the Late Byzantine age ${ }^{48}$, but why are they never mentioned before, except in the Parastaseis?

And still more: is it pure invention that the same Parastaseis claim elsewhere that Constantine's big bronze statue had been kept at the "place now called the Philadelphin" before it was brought in procession to the Forum and solemnly lifted on top of the column ${ }^{49}$, or is this an otherwise unknown piece of information from the founding days of the city?

In any case, it is almost impossible that the Capitol of Constantinople had a Christian component in it from its inception, as this has been claimed again very recently by Jason Moralee ${ }^{50}$. Instead, it certainly served the emperor's imperial cult, in one or the other way - and not only this, but there was also an imperial cult of his mother, Helena, attached to it, as I shall now try to demonstrate.

One of the most mysterious sites of Byzantine Constantinople was the place called ta Amastrianou, that is, the house or property "of the man from Amastris" Amastris, today's Amasra, is a small coastal town in Paphlagonia, in north-west

${ }^{45}$ Ibidem, p. 362-363.

${ }^{46}$ P. Speck, Das Konzept..., p. 161-163.

${ }^{47}$ Parastaseis, c. 58.

${ }^{48}$ Manuel Chrysoloras, Comparatio veteris et novae Romae, c. 49, ed. C. Billò, [in:] Manuele Crisolora, Confronto tra l'Antica e la Nuova Roma, Torino 2000, p. 6-26; see also G.P. MajeskA, Russian Travelers to Constantinople in the Fourteenth and Fifteenth Centuries, Washington D.C. 1984, p. 145.

${ }^{49}$ Parastaseis, c. 56.

${ }^{50}$ J. Moralee, Rome's Holy Mountain..., p. 108.

${ }^{51}$ On which see A. Berger, Untersuchungen zu den Patria Konstantinupoleos, Bonn 1988 [= PB, 8], p. 341-346; IDEM, Das Haus des Manns aus Amastris: Zu einem Gebäudekomplex im byzantinischen Konstantinopel, AA.ASH 51, 2011, p. 87-96. 
Asia Minor. The place ta Amastrianou was apparently a rectangular square on the southern side of the main street, the Mese, roughly opposite to the Capitol on its northern side. A semicircular courtyard in the south connected it to a monumental rotunda, probably the entrance hall of a palace which can be dated to the first decades of the fifth century ${ }^{52}$.

The rotunda collapsed at an unknown time, and its trunk was later turned into a cistern with a platform on top on which a small new palace was built. This palace, again, was converted into the Myrelaion monastery by emperor Romanus I Lakapenus around 920, with a church added on a separate substructure ${ }^{53}$. The trunk of the rotunda and the church still exist, though nothing has remained of the square in front of it or of its decoration with statues. A rather frustrating standard-class hotel occupies its place today.

The statues of ta Amastrianou are described only by the medieval sources already mentioned. The most important of them were a naked Apollo, a reclining Hercules or river god, Zeus Helios on a chariot. The Parastaseis also call the Capitol the old temple in the north and speak of a big fox of marble with an golden inlayed inscription on its chest saying "Aphrodite Selene" ${ }^{\text {. }}$. When talking about this place, Constantine of Rhodes, as quoted by the chronicle of Georgius Cedrenus, seems to believe that the palace in the south had once been a temple of Helios and Selene, of the gods of Sun and Moon ${ }^{55}$. But how can the name ta Amastrianou be explained? Who is the man from Amastris? The Patria give us the solution ${ }^{56}$ :

And there was the standing marble statue of a lord who came from the land of Paphlagonia, and another one, buried in dung and urine and dust, the slave of the Paphlagonian from Amastris. Both were sacrificed to the demons at this place and set up as a source of wonder.

Already in 1890, Julius von Schlosser had observed that at least two statues of $t a$ Amastrianou are depicted on coins from Amastris in the Roman age. One of them is Apollo, who is shown there as a naked standing figure with an arch in one hand and an unguent flask in the other, the second is a reclining Hercules ${ }^{57}$. And these statues are, without doubt, the Patria's lord with his slave from Amastris. But what is their meaning in this place? Zeus Helios on a chariot links ta Amastrianou, again, to the imperial cult of Constantine himself.

\footnotetext{
${ }^{52}$ P. NiewöHner, J. Abura, Der frühbyzantinische Rundbau beim Myrelaion in Konstantinopel. Kapitelle, Mosaiken und Ziegelstempel, IM 60, 2010, p. 411-459; R. NAUMAnN, Der antike Rundbau beim Myrelaion und der Palast Romanos I. Lekapenos, IM 50, 1966, p. 424-439.

${ }^{53}$ C.L. STriker, The Myrelaion, Bodrum Camii, in Istanbul, Princeton 1981.

${ }^{54}$ Parastaseis, c. 44.

${ }^{55}$ Cedrenus, c. 344.13 , p. 558.55 - 559.67.

${ }^{56}$ Patria, II, 52.

${ }^{57}$ J. von SCHLOSSER, Kleinasiatische und thrakische Münzbilder der Kaiserzeit, NZ 23, 1891, p. 1-28.
} 
Hans-Christoph von Mosch recently suggested that also a group of statues from ancient Lavinium may have ended up at ta Amastrianou ${ }^{58}$. Lavinium was an old city near Rome which had allegedly been founded by Aeneas himself, and Dionysius of Halicarnassus describes, in the Roman age, the statues on its forum which commemorated its foundation and consisted of an eagle, a she-wolf and a fox fighting for the fire of Vesta ${ }^{59}$. There is good reason to believe that the fox at ta Amastrianou with the inscription "Aphrodite Selene" belonged to this group, or rather, that it was a copy of it, for Dionysius speaks of bronze statues, while the statues at ta Amastrianou were of marble. In any case, the inscription connects it to the cult of the old Phenician moon goddess, which was an important part of ancestry myths of empresses who wanted to be seen as members of the gens Iulia. Its function in Constantinople, therefore, must have been to align Constantine's mother, Helena, to Aphrodite Selene in order to conceal her well-known humble origins.

We may conclude, then, that the fox and the other statues of ta Amastrianou were set up in the time of Constantine the Great himself, and that they formed a complement to the statues of the Capitol. The square ta Amastrianou was built at the same time as the Capitol and as a pendant to it, and was therefore older than the palace for which it later served as a forecourt.

So we have now, instead of one pagan cult site for the emperor himself, two of them, on the right and left side of the main avenue, one dedicated to Constantine, and another to his mother, Helena.

Let us now pass to the third and perhaps most bewildering place of Constantine's imperial cult, namely his mausoleum high on a hill in the northwest of his city.

The Life of Constantine by Eusebius reports that the emperor built a mausoleum for himself in Constantinople, where he was buried in a sarcophagus surrounded by twelve cenotaphs of the Apostles ${ }^{60}$. This suggests that the mausoleum was a rotunda, similar to other imperial graves, such as that in Rome which has survived until today as the church Santa Costanza.

\footnotetext{
${ }^{58}$ H.-C. von Mosch, Hadrians 'Sandalenlöser'. Der Hermes des Lysipp (?) auf den Münzen von Trapezous, Amastris und Markianopolis, JNG 63, 2013, p. 93-149; IDEM, Aphrodite Selene. Von der Aenadon genetrix zum problematischen Bios der Helena Augusta, JNG 67, 2017, p. 145-239.

${ }^{59}$ Dionysii Halicarnasei Antiquitatum Romanarum quae supersunt, I, 59, ed. C. JAсовY, Lipsiae 1885 [= BSGR].

${ }^{60}$ There has been a long and ongoing debate about the mausoleum and its relationship to the Church of the Apostles, to which it was attached later. See, among many others, A. Effenberger, Konstantinsmausoleum, Apostelkirche - und kein Ende?, [in:] Lithostroton. Studien zur byzantinischen Kunst und Geschichte. Festschrift für Marcell Restle, ed. B. Borkopp-Restle, T. Steppan, Stuttgart 2000, p. 67-78; P. SPECK, Konstantins Mausoleum. Zur Geschichte der Apostelkirche in Konstantinopel, [in:] IDEM, Varia 7..., p. 113-156.
} 
Constantine was thus portrayed as apostolic or even Christ-like ${ }^{61}$, in a way which became unacceptable soon after his death and led, under Constantius, to his temporary transfer to another place and to the removal of the cenotaphs.

The idea that Constantine was equal to the Apostles later found its way into the legends of the foundation of Constantinople. There, a group of twelve senators come with him from Rome and he builds houses for them in the new city. This develops, in the end, into a complete historical anecdote in which the twelve senators are even mentioned by name. All these names belong, however, in reality to houses and to persons who must be dated at least one generation after Constantine, if not more ${ }^{62}$.

But let us return to Constantine's mausoleum: In 358, the bishop Macedonius of Constantinople ordered the removal of Constantine's sarcophagus from the mausoleum, under the pretext that it was damaged and urgently needed restoration - nota bene only twenty years after the emperor's burial. Macedonius had done this without the emperor's permission and therefore lost his office ${ }^{63}$. But the previous cult in the mausoleum was never restored; Constantine's sarcophagus stood in the eastern niche of it, not in the centre, and other emperors were buried there too ${ }^{64}$. Also, a big cruciform church of the Apostles was built and inaugurated in 370 , to which the mausoleum now formed an annex. The church was replaced in the sixth century by a still more monumental construction with five domes, but the mausoleum survived until it was demolished, together with the church, after the Ottoman conquest in the $15^{\text {th }}$ century, and was replaced by the mosque of Mehmed the Conqueror.

Another pagan monument of early Constantinople which was almost forgotten in later times was the so-called Mesomphalon. It appears first in the tenth-century Patria in a short entry ${ }^{65}$.

The Mesolophon lies between the seven hills, that is, half of the city has three hills and the other has three hills, and it lies in the middle. The common people call it Mesomphalon.

The text, as it stands here, is a typical example of the pseudo-intellectual nonsense which we find so often in the Patria ${ }^{66}$. Mesomphalon, which means "middle navel", is obviously the correct word, and Mesolophon, which means "the place

\footnotetext{
${ }^{61}$ See, among others, G. DAGRon, Empereur et prêtre. Étude sur le «césaropapisme» byzantin, Paris 1996, p. $148-154$.

${ }^{62}$ A. Berger, Untersuchungen..., p. 220-224.

${ }^{63}$ P. SPECK, Konstantins Mausoleum..., p. 121-126.

${ }^{64}$ N. Asutay-Effenberger, A. Effenberger, Die Porphyrsarkophage der oströmischen Kaiser, Wiesbaden 2006, p. 52-69; P. Grierson, The Tombs and Obits of the Byzantine Emperors (337-1042), DOP 16,1962 , p. 21-23.

${ }^{65}$ Patria, III, 19; A. Berger, Untersuchungen..., p. 468-470.

${ }^{66}$ Ibidem, p. 182-185.
} 
between the hills", is just a fantastic explanation of it - which is, by the way, not very logical because six of the seven hills of Constantinople were usually located on the northern chain of hills over the Golden Horn, with the seventh hill far away in the southwest. It should be noted that the whole concept of Constantinople as a city of seven hills did not yet exist in Constantine's age, as two of these hills lie outside his city and were included only later ${ }^{67}$.

The Mesomphalon, of which we are speaking here, was a monument representing the symbolic centre of the city of Constantinople. It stood in the tradition of the so-called navel stones of ancient cities, which all follow the example of the oldest one, that of Delphi. There is no mention of it, as already said, before the tenth century, and only two short mentions in later times which show that it must have been on the northern slope of the third hill near the Golden Horn. There, in fact, the remains of a structure with curved steps was found in the 1930s, which may have once belonged to a small theatre ${ }^{68}$. Nothing is visible of it today, and since it was situated very near to the place where today the İstanbul Metro leaves the tunnel and enters the bridge over the Golden Horn, there is no chance of finding it ever again.

Such a monument had no place in a Christian city, and must therefore have been built in the early days of Constantinople. We do not know whether at any time a cult was associated with this place. But one thing we can say for sure: if the symbolic centre of the city was located here, then the original plans for Constantinople did not include an extension to the west, as it happened eighty years later when the land walls of Theodosius II were built and defined the shape of the city for the entire Byzantine age and beyond. This suggests, instead, that an extension to the north over the Golden Horn was envisaged, to the suburb of Sykai which was later known as Galata or Pera ${ }^{69}$.

So far, I have tried to show how the semi-pagan imperial cult of Constantine the Great was reflected by various monuments and buildings of his not-so-Christian city, and how its memory was lost in later times, or suppressed by Christian authors. But as I said in the beginning, the Christianisation of the empire was a long process and not completed in fewer than two hundred years after Constantine's death. The question therefore arises how his somewhat awkward religious policies were perceived by followers of the traditional Roman and Greek religion. This leads me to my last example, the cult of the city goddess, the Tyche of Constantinople. In his report on the foundation of Constantinople, Ioannes Malalas also says ${ }^{70}$ :

\footnotetext{
${ }^{67}$ See A. Berger, Das apokalyptische Konstantinopel. Topographisches in apokalyptischen Schriften der mittelbyzantinischen Zeit, [in:] Endzeiten. Eschatologie in den monotheistischen Weltreligionen, ed. W. Brandes, F. Schmieder, Berlin 2008, p. 139-146.

${ }^{68}$ A.M. SCHNeIDER, Byzanz, Berlin 1936, p. 93 (no. 13) with plate 9.

${ }^{69}$ A. Berger, Regionen..., p. 410-411.

${ }^{70}$ After the passage quoted at n. 29 above.
} 
The Tyche of the city, which he had renewed and built in his name, he called Anthousa, offering a bloodless sacrifice to God.

The iconography of this Tyche is well known from coins and other representations: she had a mural crown on her head, a cornucopia in her hand, and her foot set upon a ship's bow ${ }^{71}$. Later in the Byzantine age, several statues or reliefs representing Tyche are mentioned by the sources without further comment. But the last pagan historian of the Roman empire, Zosimus, who wrote shortly before Malalas and depicts Constantine in the darkest light, gives us this account ${ }^{72}$ :

In Byzantium there was a very large market-place with four porticos. There he erected two temples at the end of one of them, to which a flight of numerous steps ascends. There he placed the statue of Rhea, the mother of the gods, which Jason's companions had once set up on Mount Dindymon, which is near the city of Cyzicus. People say that through his contempt of religion he impaired this statue by taking away the lions that were on each side, and by changing the position of the hands. While she seemed to hold the lions before, she was now altered into a supplicating posture, looking towards the city and watching it. In the other temple he placed the statue of the Fortune of Rome.

This is really a nice story, and we should really hope that it is true, and that indeed an old statue of Kybele from Mount Dindymon - the peninsula near today's Bandirma on the southern coast of the Sea of Marmara - was changed in this way into a city goddess of Constantinople. Kybele was usually depicted with a high headgear, the so-called polos, which could easily be interpreted as a mural crown appropriate for a city goddess. Zosimus, however, was no contemporary himself and must be read with some caution, for other sources know only one temple of the Tyche of Constantinople $^{73}$. It stood near the market-place also called the Basilica in the city centre, and was later converted into the so-called Milion, the Golden Milestone of Constantinople ${ }^{74}$. What Zosimus teaches us is, in the end, quite clear: Constantine may not have been a good Christian, but he was not a good pagan either.

Constantinople became a Christian capital, and continued to exist as such for more than thousand years, while the memory of its not-so-Christian origins slowly faded away. And in the end, Constantinople was no more the city of Constantine, but the city of the Mother of God. It lies, however, beyond the scope of this paper to discuss this phenomenon and its development ${ }^{75}$.

\footnotetext{
${ }^{71}$ G. BüHL, Constantinopolis und Roma. Stadtpersonifikationen der Spätantike, Kilchberg-Zürich 1995 [= ACre, 3], p. 9-78.

${ }^{72}$ Zosime, Histoire nouvelle, II, 31, 2-3, ed. et trans. F. Paschoud, Paris 1971-1989 [= CUF.SG], p. 104-105.

${ }^{73}$ Hesychius, c. 15.

${ }^{74}$ A. Berger, Untersuchungen..., p. 271-274.

${ }^{75}$ See, among others, Av. Cameron, The Theotokos in sixth-century Constantinople: A City Finds its Symbol, JTS 29, 1978, p. 79-108; C. Mango, Constantinople as Theotokoupolis, [in:] Mother of God. Representations of the Virgin in Byzantine Art, ed. M. VAssiLAKI, Milan 2000, p. 17-25.
} 


\section{Bibliography}

\section{Primary Sources}

Accounts of Medieval Constantinople. The Patria, trans. A. Berger, Cambridge Mass. 2013 [= Dumbarton Oaks Medieval Library, 24].

Annae Comnenae Alexias, rec. D.R. ReInsch, A. Kambylis, Berolini 2001 [= Corpus fontium historiae byzantinae, 40].

The Chronicle of John Malalas, trans. E. Jefrreys, M. Jeffreys, R. Scott et al., Melbourne 1986 [= Byzantina Australiensia, 4].

Chronicon paschale, ed. L. Dindorf, Bonnae 1832 [= Corpus scriptorum historiae byzantinae].

Constantine of Rhodes, On Constantinople and the Church of the Holy Apostles, ed. L. James, I. Vassis, trans. V. Dimitropoulou, L. James, R. Jordan, Farnham 2012.

Constantinople in the Early Eighth Century. The Parastaseis Syntomoi Chronikai, ed. Av. Cameron, J. Herrin, Leiden 1984 [= Columbia Studies in the Classical Tradition, 10].

Dionysii Halicarnasei Antiquitatum Romanarum quae supersunt, ed. C. JACoBy, Lipsiae 1885 [= Bibliotheca scriptorum Graecorum et Romanorum Teubneriana].

Eusebius, Life of Constantine, trans. Av. Cameron, S. Hall, New York 1999.

Eusebius Werke, vol. I.1, Über das Leben des Kaisers Konstantin, ed. F. Winkelmann, ${ }^{2}$ Berlin 1974 [= Die griechischen christlichen Schriftsteller der ersten [drei] Jahrhunderte, 7.1].

Eusebius Werke, vol. VII, Hieronymi Chronicon, ed. R. HeLm, Berlin 1956 [= Die griechischen christlichen Schriftsteller der ersten [drei] Jahrhunderte, 47].

Georgii Cedreni Historiarum compendium, ed. L. TARTAGLIA, Roma 2016 [= Bollettino dei classici, 30].

Hesychii Illustrii origines Constantinopolitanae, [in:] Scriptores originum Constantinopolitanarum, vol. I, rec. T. PREGER, Lipsiae 1901 [= Bibliotheca scriptorum Graecorum et Romanorum Teubneriana].

Ioannis Malalae Chronographia, rec. I. ThuRn, Berolini 2000 [= Corpus fontium historiae byzantinae, 35], https://doi.org/10.1515/9783110876017

Magoulias H., O City of Byzantium. Annals of Niketas Choniates, Detroit 1984.

Manuel Chrysoloras, Comparatio veteris et novae Romae, ed. C. Billò, [in:] Manuele Crisolora, Confronto tra l'Antica e la Nuova Roma, Torino 2000.

Nicetae Choniatae historia, rec. J. van Dieten, Berolini 1975 [= Corpus fontium historiae byzantinae. Series Berolinensis, 11].

Patria Constantinopoleos, [in:] Scriptores originum Constantinopolitanarum, vol. II, rec. T. PREger, Lipsiae 1907 [= Bibliotheca scriptorum Graecorum et Romanorum Teubneriana].

Philostorgius, Kirchengeschichte, ed. F. Winkelmann, J. Bidez, ${ }^{3}$ Berlin 1981 [= Die griechischen christlichen Schriftsteller der ersten [drei] Jahrhunderte, 21].

Zosime, Histoire nouvelle, ed. et trans. F. Paschoud, Paris 1971-1989 [= Collection des Universités de France. Série grecque]. 


\section{Secondary Literature}

Asutay-Effenberger N., Effenberger A., Die Porphyrsarkophage der oströmischen Kaiser, Wiesbaden 2006.

Bardill J., Constantine, Divine Emperor of the Christian Golden Age, Cambridge 2012.

Barnes T.D., Constantine and Eusebius, Cambridge Mass. 1981.

BARnes T.D., Constantine's Prohibition of Pagan Sacrifice, “American Journal of Philology" 105, 1984, p. 69-72, https://doi.org/10.2307/294627

Bassett S., The Urban Image of Late Antique Constantinople, Cambridge 2004.

Berger A., Das apokalyptische Konstantinopel. Topographisches in apokalyptischen Schriften der mittelbyzantinischen Zeit, [in:] Endzeiten. Eschatologie in den monotheistischen Weltreligionen, ed. W. Brandes, F. Schmieder, Berlin 2008, p. 137-155.

Berger A., Das Haus des Manns aus Amastris: Zu einem Gebäudekomplex im byzantinischen Konstantinopel, "Acta antiqua Academiae Scientiarum Hungaricae" 51, 2011, p. 87-96, https://doi. org/10.1556/AAnt.51.2011.2.2

Berger A., Regionen und Straßen im frühen Konstantinopel, "Istanbuler Mitteilungen” 47, 1997, p. 349-414.

Berger A., Untersuchungen zu den Patria Konstantinupoleos, Bonn 1988 [= Poikila Byzantina, 8].

BüHL G., Constantinopolis und Roma. Stadtpersonifikationen der Spätantike, Kilchberg-Zürich 1995 [= Akanthus crescens, 3].

Cameron A., The Last Pagans of Rome, Oxford 2011, https://doi.org/10.1093/acprof:oso/9780199 747276.001.0001

Cameron Av., The Theotokos in Sixth-century Constantinople: A City Finds its Symbol, "The Journal of Theological Studies" 29, 1978, p. 79-108, https://doi.org/10.1093/jts/XXIX.1.79

CoüAsnon C., The Church of the Holy Sepulchre in Jerusalem, London 1974.

DAGron G., Empereur et prêtre. Étude sur le «césaropapisme» byzantin, Paris 1996.

Dagron G., Naissance d'une capitale. Constantinople et ses institutions de 330 à 451, Paris 1974.

EfFenberger A., Konstantinsmausoleum, Apostelkirche - und kein Ende?, [in:] Lithostroton. Studien zur byzantinischen Kunst und Geschichte. Festschrift für Marcell Restle, ed. B. BORKopp-Restle, T. STEPPAN, Stuttgart 2000, p. 67-78.

Effenberger A., Zur Wiederverwendung der venezianischen Tetrarchengruppen in Konstantinopel, "Millennium" 10, 2013, p. 215-274, https://doi.org/10.1515/mjb.2013.10.1.215

GréGolre H., La 'conversion' de Constantin, “Revue de l'Université de Bruxelles” 36, 1930-1931, p. 231-272.

Grégolre H., Eusèbe n'est pas l'auteur de la 'Vita Constantini' dans sa forme actuelle et Constantin ne s'est pas converti en 312, "Byzantion. Revue internationale des études byzantines" 13, 1938, p. 561-583.

Grierson P., The Tombs and Obits of the Byzantine Emperors (337-1042), "Dumbarton Oaks Papers" 16, 1962, p. 1-63, https://doi.org/10.2307/1291157

Jacoff M., The Horses of San Marco and the Quadriga of the Lord, Princeton N.J. 1993.

JaNin R., Constantinople byzantine. Développement urbain et répertoire topographique, ${ }^{2}$ Paris 1964.

Lathoud D., La consécration et la dédicace de Constantinople, "Échos d'Orient" 23, 1924, p. 289-314, https://doi.org/10.3406/rebyz.1924.4464

MacMullen R., Christianizing the Roman Empire (A.D. 100-400), New Haven 1984. 
Majeska G.P., Russian Travelers to Constantinople in the Fourteenth and Fifteenth Centuries, Washington D.C. 1984.

Mango C., Antique Statuary and the Byzantine Beholder, “Dumbarton Oaks Papers” 17, 1963, p. 53-75, https://doi.org/10.2307/1291190

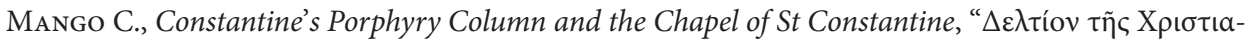

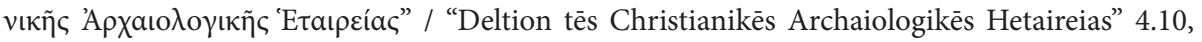
1981, p. 103-110, https://doi.org/10.12681/dchae.901

Mango C., Constantinople as Theotokoupolis, [in:] Mother of God. Representations of the Virgin in Byzantine Art, ed. M. Vassilaki, Milan 2000, p. 17-25.

Mango C., Le développement urbain des Constantinople ( $I V^{e}-V I I^{e}$ siècles), ${ }^{2}$ Paris 1990 [= Travaux et mémoires du Centre de recherche d'histoire et civilisation de Byzance, Collège de France. Monographies].

Moralee J., Rome's Holy Mountain. The Capitoline Hill in Late Antiquity, Oxford 2018 [= Oxford Studies in Late Antiquity], https://doi.org/10.1093/oso/9780190492274.003.0002

Mosch H.-C. von, Aphrodite Selene. Von der Aenadon genetrix zum problematischen Bios der Helena Augusta, "Jahrbuch für Numismatik und Geldgeschichte" 67, 2017, p. 145-239.

Mosch H.-C. von, Hadrians 'Sandalenlöser'. Der Hermes des Lysipp (?) auf den Münzen von Trapezous, Amastris und Markianopolis, "Jahrbuch für Numismatik und Geldgeschichte" 63, 2013, p. 93-149.

Naumann R., Der antike Rundbau beim Myrelaion und der Palast Romanos I. Lekapenos, "Istanbuler Mitteilungen" 50, 1966, p. 424-439.

NiewöHner P., Abura J., Der frühbyzantinische Rundbau beim Myrelaion in Konstantinopel. Kapitelle, Mosaiken und Ziegelstempel, "Istanbuler Mitteilungen" 60, 2010, p. 411-459.

Niewöhner P., Peschlow U., Neues zu den Tetrarchenfiguren in Venedig und zu ihrer Aufstellung in Konstantinopel, "Istanbuler Mitteilungen" 62, 2012, p. 341-367.

Odorico P., Du recueil à l'invention du texte: le cas des Parastaseis syntomoi chronikai, "Byzantinische Zeitschrift" 107, 2014, p. 755-784, https://doi.org/10.1515/bz-2014-0019

Rathmann M., Tabula Peutingeriana. Die einzige Weltkarte aus der Antike, ${ }^{3}$ Darmstadt 2018.

Schlosser J. von, Kleinasiatische und thrakische Münzbilder der Kaiserzeit, "Numismatische Zeitschrift" 23, 1891, p. 1-28.

SCHNeIder A.M., Byzanz, Berlin 1936.

SPECK P., Konstantins Mausoleum. Zur Geschichte der Apostelkirche in Konstantinopel, [in:] P. SPECK, Varia 7, Bonn 2000, p. 113-156.

Speck P., Das Konzept Konstantins des Großen für Konstantinopel: Die Umgestaltung der Audienzhalle zur Hagia Sophia und das Schicksal des Kapitols, [in:] P. Speck, Varia 7, Bonn 2000, p. 157-165.

Striker C.L., The Myrelaion, Bodrum Camii, in Istanbul, Princeton 1981.

Van Dam R., The Roman Revolution of Constantine, Cambridge 2007, https://doi.org/10.1017/CBO 9780511819476

Verzone P., I gruppi di porfido in S. Marco a Venezia ed il Philadelphion di Costantinopoli, "Palladio" 1,1958 , p. 8-14.

Wallraff M., Die antipaganen Maßnahmen Konstantins in der Darstellung des Euseb von Kaisareia, [in:] Spätantiker Staat und religiöser Konflikt. Imperiale und lokale Verwaltung und die Gewalt gegen Heiligtümer, ed. J. HaHN, Berlin 2011 [= Millennium-Studien, 34], p. 7-18, https://doi. org/10.1515/9783110240887.7 
Abstract. In his new city Constantinople, Constantine the Great established an imperial cult with pagan elements prevailing over Christian ones. This can be seen from a number of monuments and buildings, such as the Forum of Constantine with the emperor's statue on a column, the Capitol, the emperor's mausoleum, the Mesomphalon, and the temple of the city goddess Tyche.

Keywords: Constantine the Great, religious policies; Constantinople, foundation; Constantinople, ancient statuary

Albrecht Berger

Ludwig-Maximilians-Universität München

Lehrstuhl für Byzantinistik

Geschwister-Scholl-Platz 1

80539 München, Germany

albrecht.berger@lmu.de 